Hope Is an Imperative 
Previous publications by David W. Orr

Down to the Wire (Oxford, 2009)

Design on the Edge (MIT Press, 2006)

The Last Refuge (Island Press, 2004)

The Nature of Design (Oxford, 2002)

Earth in Mind (Island Press, 1994/2004)

Ecological Literacy (State University of New York Press, 1992)

Sage Handbook of Environment and Society (Sage Publications, 2007) edited with Jules Pretty et al.

The Campus and Environmental Responsibility (Jossey-Bass, 1992) edited with David Eagan

The Global Predicament: Ecological Perspectives on World Order

(University of North Carolina Press, 1979)

edited with Marvin Soroos 


\section{Hope Is an}

Imperative

The Essential David Orr

$$
\text { ケ }
$$

\section{David W.Orr}

Foreword by Fritjof Capra

\section{Oislandpress}

Washington | Covelo | London 


\section{Hope Is an Imperative: The Essential David Orr}

\section{(C) 2011 David W. Orr}

Grateful acknowledgment is made to all those who granted permission to reprint the selections in Hope Is an Imperative. A complete list of permissions can be found on page 353 .

All rights reserved under International and Pan-American Copyright Conventions. No part of this book may be reproduced in any form or by any means without permission in writing from the publisher: Island Press,

Suite 300, I718 Connecticut Ave., NW, Washington, DC 20009.

ISLAND PRESS is a trademark of the Center for Resource Economics.

Library of Congress Cataloging-in-Publication Data Orr, David W., I944-

Hope is an imperative : the essential David Orr / David W. Orr ; foreword by Fritjof Capra.

p. cm.

Includes bibliographical references and index. ISBN-I3: 978-I-59726-699-4 (cloth : alk. paper) ISBN-IO: I-59726-699-X (cloth : alk. paper) ISBN-I3: 978-I-59726-700-7 (pbk. : alk. paper) ISBN-IO: I-59726-700-7 (pbk. : alk. paper)

1. Environmental quality. 2. Sustainability. 3. Environmental education. 4. Human ecology. 5. Sustainable design. 6. Environmental engineering. 7. Global environmental change. 8. Climatic changesEnvironmental aspects. I. Title.

$$
\begin{gathered}
\text { GEI4O.077 2OII } \\
333.72-\mathrm{dc} 22
\end{gathered}
$$

Printed on recycled, acid-free paper

Keywords: Ecological design, sustainability, education, energy and climate, climate change, ecological literacy, environmental essays, environmental movement, environmental studies, green campus movement, energy policy, architectural design

Manufactured in the United States of America I0 9877654332 I 


To David Ehrenfeld 



\section{$\therefore$ Contents :}

Foreword by Fritjof Capra xi

Introduction $x v$

PART I: The Fundamentals

I. Verbicide 5

2. Slow Knowledge I3

3. Speed $2 I$

4. Love 30

5. Reflections on Water and Oil 35

6. Gratitude $4 I$

7. Orr's Laws 46

\section{PART 2: On Sustainability}

8. Walking North on a Southbound Train 57

9. Four Challenges of Sustainability 66

Io. The Problem of Sustainability 73

II. Two Meanings of Sustainability 93

I2. Leverage ${ }_{I I 2}$

13. Shelf Life II8

I4. The Constitution of Nature $\quad{ }_{226}$

I5. Diversity 139

I6. All Sustainability Is Local:

New Wilmington, Pennsylvania $\quad{ }^{445}$ 


\section{PART 3: On Ecological Design}

I7. Designing Minds

165

18. Loving Children: A Design Problem

172

19. Further Reflections on Architecture as Pedagogy

180

20. The Origins of Ecological Design

I86

2I. The Design Revolution: Notes for Practitioners

198

\section{PART 4: On Education}

22. Place as Teacher

23. The Problem of Education

229

24. What Is Education For?

237

25. Some Thoughts on Intelligence

246

26. Ecological Literacy

27. Place and Pedagogy

262

28. The Liberal Arts, the Campus, and the Biosphere

270

PART 5: On Energy and Climate

29. Pascal's Wager and Economics in a Hotter Time

30. The Carbon Connection

292

31. 2020: A Proposal

32. Baggage: The Case for Climate Mitigation

308

33. Long Tails and Ethics: Thinking about the Unthinkable

34. Hope (in a Hotter Time)

35. At the End of Our Tether?

The Rationality of Nonviolence

Sources

Permissions

About David W. Orr

Index 


\section{$\therefore$ Foreword :}

As the tWenty-First CENTURY unfolds, it is becoming increasingly evident that the state of our natural environment is no longer one of many "single issues." It is the context of everything else — of our lives, our work, our politics.

The great challenge of our time is to build and nurture communities that are ecologically sustainable. As David Orr explains in this fine collection of essays, a sustainable community is designed in such a manner that its ways of life, businesses, economy, physical structures, and technologies respect, honor, and cooperate with nature's inherent ability to sustain life.

The first step in this endeavor must be to understand the basic principles of organization that the Earth's ecosystems have evolved over billions of years to sustain the web of life. We need to understand the language of nature, as it were-its flows and cycles, its networks and feedback loops, and its fluctuating patterns of growth and development. Almost 20 years ago, David Orr coined the term ecological literacy for this basic ecological knowledge and chose it as the title of his first book. Since then, ecological literacy, or ecoliteracy, has become a widely used concept within the environmental movement. Being ecologically literate means understanding the basic principles of ecology and living accordingly.

Ecoliteracy is the first step on the road to sustainability; the second step is ecodesign. We must apply our ecological knowledge to the fundamental redesign of our technologies, physical structures, and social institutions so as to bridge the current gap between human design and the ecologically sustainable systems of nature. 
Design, in David Orr's memorable phrase, consists in "shaping flows of energy and materials for human purposes." Ecodesign, he writes, is "the careful meshing of human purposes with the larger patterns and flows of the natural world." Thus, ecodesign principles reflect the principles of organization that nature has evolved to sustain the web of life.

Once we become ecologically literate, once we understand the processes and patterns of relationships that enable ecosystems to sustain life, we will also understand the many ways in which our human civilization, especially since the Industrial Revolution, has ignored or interfered with these ecological patterns and processes. And we will realize that these interferences are the fundamental causes of many of our current world problems.

Because of the fundamental interconnectedness of the entire biosphere, the problems caused by our harmful interferences are also fundamentally interconnected. None of the major problems of our time can be understood in isolation. They are systemic problems-all interdependent and mutually reinforcing - and they require corresponding systemic solutions. Thinking systemically means thinking in terms of relationships, patterns, and context. To use a popular phrase, it means being able to "connect the dots."

The interconnectedness of world problems, the need to become ecologically literate, and the principles of ecodesign are three major strands that weave through the essays in this book. David Orr is a systemic thinker par excellence and a longtime friend and colleague whose thoughts and writings have influenced and inspired my own work for many years. With impeccable clarity, he demonstrates again and again that the current obsession of economists and politicians with unending growth is a fatal illusion; that our persistent failure to formulate sound energy policies has resulted in terrorism, oil wars, economic vulnerability, and climate change; that climate change is a challenge not only to consumerism and the growth economy but also to our political institutions, worldviews, and philosophies.

While all these systemic links are lucidly analyzed, David's writing is also deeply moving, thoughtful, and poetic. His intention is always to foster and expand our awareness of "the connections that bind us to each other, to all life, and to all life to come." I am really glad that Island Press is now publishing David's essential writings in one volume. They include many of his classic essays, which I have savored again and again over the years-for example, Place and Pedagogy, What Is Education 
For?, Loving Children: A Design Problem, and my personal favorite, Slow Knowledge.

This book is both wake-up call and inspiration. Its trenchant analysis of the dire state of our world, combined with its passionate call to action, remind me of the famous maxim by the Italian political theorist Antonio Gramsci that we need both the pessimism of the intellect and the optimism of the will. Or, as David himself puts it in his introduction, "Hope is a verb with its sleeves rolled up."

These essays are eloquent and full of great wisdom. But what shines through them most of all is their author's deep passion for humanity and for the living Earth.

Fritjof Capra, founding director Center for Ecoliteracy Berkeley, California 



\section{$\therefore$ Introduction :}

FOR BAD ELECTRICAL WIRING, the sensible response is to call an electrician sooner than later. When sparks fly, the sensible thing to do is pull the breaker and reach for the fire extinguisher. When the house is on fire, the sensible thing to do is to call the fire department. But it would not be sensible to call the fire department when the problem is bad wiring or to call an electrician when the house is on fire. The word sensible, in other words, is relative to the gravity of the situation.

In the past quarter century, something analogous has happened to us as a nation and to the entire planet. Faced with the overwhelming evidence of environmental stresses, it would have been sensible decades ago to assemble the expertise necessary to redesign energy, food, materials, and manufacturing systems in order to eliminate waste and to coincide with laws of physics and ecology. As things worsened, it would have been sensible to develop global responses by aggressively implementing Agenda 2I, the Rio Accords, the Kyoto Protocol, and more. Now, in the second decade of the twenty-first century, it would be sensible to recognize that we have squandered any margin of safety we once had and are in a planetary emergency and need to act accordingly. But there is no global equivalent of a 9II call and no intergalactic emergency squad to come to our rescue. It's up to us.

Meanwhile, as the years tick by, we are nearing (some say we have passed) irreversible and irrevocable changes in the oceans, atmosphere, soils, forests, and entire ecosystems. Now the sensible things we must do everywhere are merely extraordinary, unprecedented, and heroic at a scale sufficient to avert global catastrophe. 
We are in the process of evicting ourselves from the only paradise humankind has ever known-what geologists call the Holocene. This I2,000-year age has been abnormally benign with a relatively stable and warm climate, more or less perfect for the emergence of Homo sapiens. But $\mathrm{CO}_{2}$ levels are now higher than they've been in hundreds of thousands of years and rising still higher each year. We are creating a different and more capricious and hostile planet than the one we've known for thousands of years-what writer and activist Bill McKibben denotes as "Eaarth" (McKibben 20IO). The challenge of living on this emerging planet is the challenge of our time, exempting no one, no organization, no nation, and no generation from here on as far as one can imagine.

The essays that follow, now the chapters of this book, were written between 1985 and 2010 as human civilization entered the historical equivalent of rapids on a white-water river. No one knows whether the frail craft of civilization will capsize because of climate destabilization, terrorism, economic collapse, technology run amuck, governmental ineptitude, or any number of other threats or whether it will somehow survive, chastened and hopefully improved. It is clear, however, that our previous unwillingness to do what was sensible, obvious, and necessary has now rendered our situation far more difficult and dangerous than it otherwise might have been.

Every writer works with the refracted influences of other people, places, and experiences. My interest in things environmental was enhanced by the great landscape architect Ian McHarg in the early I970s when I was a doctoral student at the University of Pennsylvania. I was inspired to read everything I could find on the subject and discovered that the study of the "environment" came with an imperative to roam intellectually in order to connect things otherwise isolated by department, discipline, and narrow perspectives. But despite the great range and diversity of disciplines and perspectives necessary to an informed ecological worldview, the subject comes down to the one big question of how we fairly, durably, and quickly remake the human presence on Earth to fit the limits of the biosphere while preserving hard-won gains in the arts, sciences, law, the open society, and governance, which is to say civilization.

The urgency and excitement of that time was palpable. Some of the best thinking and writing ever about the human place in nature occurred in that decade. New nongovernmental organizations formed to defend particular places, ecologies, and the larger environment. The U.S. political system responded by creating the Environmental Protection Agency 
and the Council on Environmental Quality. Republicans and Democrats worked together to establish a National Environmental Policy and pass legislation to protect air, water, rivers, wilderness, open space, and endangered species. There were surely differences between Democrats and Republicans, but not paralysis, because there were still enough people in government with a sufficient regard for the issues that bind us together, to the web of life, and to all life to come to justify rethinking crusty old ideas and crossing party lines from time to time in order to protect the common good.

No road map existed then to define the path ahead, but by the late I97os a global conversation about the sustainability of humankind was gathering steam. Many of us were optimistic that with enough science, better technology, and rational policy reforms, monumental problems could be solved. In hindsight it is obvious that things were not so simple, and neither are they today. Many factors come between what we should do and what we actually do, beginning with the daunting complexity of the problems and potential responses, whether market based or led by government or by cultural change, or all of the above. As well, we have to contend with competing political and economic interests that have become rigid ideologies rooted in tattered beliefs that humans can do as they please with nature without consequences. The stranglehold of bad ideas is deeply rooted often in the inability or unwillingness to see what's right before our eyes. And always the gap between what we should do and what we actually do is widened by ignorance, garden-variety stupidity, and the tendency to put off to tomorrow what should have been done yesterday. And lurking in the shadows there is the darker side of human nature that can't be wished away. But the fact remains that we know enough to act much better than we do. More science and better technology won't be nearly enough without a larger and more rational rationality. And even that won't suffice without summoning help from what Abraham Lincoln once called "the better angels of our nature."

The perplexities of human nature aside, we navigate between two rapidly flowing currents. Nothing in nature is static, but we have accelerated the pace of ecological change to a rate that rivals or exceeds that of the great extinction events of the distant past. The other current is the quickening pace of technological, demographic, social, and economic changes. In such unpredictable circumstances, no one can say for sure what it means for humankind to come to terms with nature, but we know that the road ahead will not be easy or smooth. Along the way, we will be tempted to do 
things that in less vexing times we would recognize as foolish or risky. We will be urged to deploy magic bullet technologies with vast implications without dealing with underlying problems or larger systemic issues. As long as civilization lasts, however, we will have to monitor and manage our demands and impacts on the planet and find widely acceptable and effective ways to limit what we do, whether by law, regulation, cultural norms, or religion or by some other means. We will also have to muster the wisdom to confront old and contentious issues having to do with the fair distribution of wealth and the balance of rights between generations and between humans and other life-forms. That in turn will require robust and competent governments and an ecologically literate and competent citizenry. However such things play out, we've long since passed the time when we could change atmospheric chemistry or the acidity of oceans, or unravel ecologies, or even procreate with little thought for the morrow or the health of the larger whole.

I have organized this collection of essays in five parts that reflect issues and subjects that caught my attention over the past 25 years. Most all of the essays were initially written as aids in solving one practical problem or another. Running through the entire book is the question of how humankind can fit harmoniously in the ecosphere - which invites controversy, multiple opinions, and lots of conjecture. I have only lightly edited the chapters to take out redundancies and update where necessary, so they are mostly as initially published but with fewer references and without footnotes.

The first part deals with fundamental principles. I'll let those essays speak for themselves without further comment and without any presumption that they are exhaustive or scriptural, including the one presumptuously titled "Orr's Laws." The second part, on the challenges of sustainability, is a bit like a brush-clearing operation that aims to get the lay of the land. However conceived, described, or analyzed, sustainability is the issue of our time, all others being subordinate to the global conversation now under way about whether, how, and under what terms the human experiment will continue.

The third part deals with possible responses to the challenges of sustainability. Most, if not all, of our environmental problems result from poor design - factories that produce more waste than product; buildings that squander energy; farms that bleed soil, excess nitrogen, and pollution; cities designed to sprawl; and so forth. The logical response, then, is better design or what is coming to be known as ecological design. It includes 
the design professions such as architecture and engineering but is a much bigger enterprise. It is quite literally about what $\mathrm{McHarg}$ described as "design with nature" in order to remake the human place on Earth. But the change toward ecological design in the fields of urban planning, agriculture, manufacturing, and energy systems as well as architecture will require a major change in how we think and so changes in education at all levels.

The fourth part, then, deals with education and specifically with the problem of education, not problems in education. Tinkering at the edge of the status quo characteristic of most educational reforms is a kind of nickel solution to a dollar-sized problem. But in the not-too-distant future, I can imagine schools, colleges, and universities designed ecologically, becoming models for the transition ahead and leaders toward a better future than the one now on the horizon. But that future is now clouded by the largest challenge humankind has ever faced, which is the onset of rapid climate destabilization.

The final part of the book is the most troubling of all and requires more explanation. We are, indeed, evicting ourselves from the very conditions in which we emerged as a species. Everything we've done-all of our accomplishments and failures, our arts, literatures, cultures, history, and organizations - occurred under, and partially because of, conditions that we are now changing for the worse. The increasing temperature of Earth, rising seas, extinction of species, changing hydrology, and shifting ecologies are effectively permanent changes that will render the future progressively more difficult for our descendants. That fact runs against the grain of the American tendency to regard problems as always solvable with enough technology or money. But the climate destabilization now under way is not solvable in that sense. We hope that the worst can be contained, but as geophysicist David Archer and others point out, we have already set planet-changing forces in motion that cannot be stabilized for centuries. If there was ever an issue that required clarity of mind, steadiness of purpose, and wisdom, this is it. I close with thoughts on the nature of hope in a progressively hotter and less stable ecosphere. But hope is a verb with its sleeves rolled up. In contrast to optimism or despair, hope requires that one actually do something to improve the world. Authentic hope comes with an imperative to act. There is no such thing as passive hope.

My thinking and writing have been much influenced by some of the great minds and personalities of our time. This book is gratefully 
dedicated to one such person, David Ehrenfeld, who is a physician, a biologist, a teacher, a renaissance man, and a friend and a teacher to me and many others. As the founding editor of Conservation Biology, David invited me to write many of the essays included here and helped to improve the results.

I also gratefully acknowledge Gary Meffe, who, like David Ehrenfeld, served with great distinction as editor of Conservation Biology and in that capacity improved the column I wrote for 20 years. Whatever clarity and felicity are evident in those essays included here owe much to David and Gary's skill, judgment, and, not the least, friendship.

For many years Wes Jackson has been a friend, provocateur, teacher, and a source of some of the best humor I've ever heard. His life has been one long seminar on soils, farming, civilization, philosophy, religion, ecology, literature, and more and how all of this is related. In long telephone conversations and visits to the Land Institute in Salina, I have been privileged to be a part of many of those mostly impromptu and brilliant sessions which I count mostly as a blessing, occasionally as an irritant, but always as convivial and often profound stimulation.

It is not possible to acknowledge Wes Jackson without saying an appreciative word about Wendell Berry. One of the most interesting and important dialogues of our time is that between Jackson and Berry, who over three decades have mutually influenced each other in a synergy of science, literature, good stories, friendship, inspiration, and devotion to land, agriculture, and rural people. Wendell Berry is described variously as a prophetic voice, one of the great writers of our time, and the wisest among us, all of which I believe to be true. For more than 40 years he has eloquently probed and defined our connections to land and community without ever being repetitive or tiresome. Above all, he has taught us the importance of words faithfully spoken and lived and our connectedness to places and real communities.

Finally, I thank Barbara Dean, Todd Baldwin, and Chuck Savitt at Island Press for their editorial help, advice, and friendship. And I gratefully confess to having been improved, instructed, inspired, sometimes chastised, but always nurtured by many others too numerous to list. But to all, my thanks for much that is beyond the saying. 